\title{
DISCUSSION
}

\section{Biopolitics and the Coronavirus}

\author{
Foucault, Agamben, Žižek
}

\author{
Lukas van den Berge
}

As described by Michel Foucault in Discipline and Punish, measures to be taken in the case of an epidemic in the French town of Vincennes in the seventeenth century include what is currently known as a full lockdown, Chinese style. ${ }^{1}$ The gates of the city are closed and people are confined in their own houses, with the doors of each house being barred from the outside by representatives of the government. The streets and other public spaces are occupied by a well-ordered militia of syndics and sentinels serving as the population's meticulous guards and inspectors. Foucault's account of these measures serves as an overture to his description of panopticism as a modern form of government. As Foucault has it, 'the plague as a form, both real and imaginary, of disorder' finally served to legitimate 'the penetration of regulation into even the smallest details of everyday life'. ${ }^{2}$ The haunting memory of epidemics and the chaos associated with it would thus have paved the way for 'biopolitics' as a system of constant surveillance and discipline in which governmental control pertains directly to the physical existence of citizens. $^{3}$

In related fashion, Giorgio Agamben has diagnosed modern policies and practices of state control over the bodies of citizens as the 'biopolitical paradigm of the modern', a 'concealed matrix' of contemporary political life that usually hides behind the civilized mask of liberal democracy. ${ }^{4}$ In times of emergency, however, modern state power would tend to show its true face, resorting to the 'state of exception' in which the bare life of citizens is subject to unmediated power. ${ }^{5}$ In Agamben's view, the current response to the outbreak of the coronavirus in western countries is just another example of this. With terrorism exhausted as a legitimation for exceptional measures, the 'invention of an epidemic' would now serve

1 Michel Foucault, Discipline and Punish: The Birth of the Prison, tr. Alan Sheridan (New York: Pantheon Books, 1977), 195-200.

2 Foucault, Discipline and Punish, 197-198.

3 See, e.g., Michel Foucault, Security, Territory, Population. Lectures at the Collège de France 1977-1978, ed. Michel Senellart, tr. Graham Burchell (New York: Palgrave Macmillan, 2007), 1-28, with specific regard to the management of epidemics at 24-26. For a handsome overview of Foucault's concept of biopolitics more in general, see Thomas Lemke, Biopolitics (New York: New York University Press, 2011), 33-52.

4 Giorgio Agamben, Homo Sacer: Sovereign Power and Bare Life, tr. Daniel Heller-Roazen (Stanford: Stanford University Press, 1998), 69; 99.

5 Giorgio Agamben, State of Exception, tr. Kevin Attell (Chicago: University of Chicago Press, 2005), $1-31$. 
as an ideal pretext for scaling up such measures almost beyond limitation. In a weblog dating from 26 February 2020, with the number of confirmed corona cases in northern Italy quickly rising, Agamben defies some of the early decrees issued by the government as 'frenetic, irrational and entirely unfounded'. Those decrees would amount to a response that is completely disproportionate with regard to an illness that is 'not too different from the normal flus that affect us every year'. 6

Understandably, Agamben's defiance of emergency measures and his assessment of Covid-19 as an 'invented epidemic' sparked fierce reactions. 'Monitor and punish? Yes, please', Slovenian intellectual Slavoj Žižek contends in a recent reply. ${ }^{7}$ As Žižek has it, Agamben's reaction is 'the extreme form of a widespread Leftist stance' of dismissing any form of monitoring as repressive surveillance and any form of active governance as a clear proof of hidden totalitarianism'. Such easy Foucauldian criticism, as Žižek astutely remarks, will not make the reality of the threat go away. Whereas the privileged are most likely to come out of the crisis relatively unscathed, those already living under precarious circumstances will probably receive the hardest blows, especially if the government forsakes to take active steps to reduce new infections. On similar grounds, Tim Christiaens - a researcher from KU Leuven - even argued that 'society must be defended from Agamben' as he has now turned out to be a 'coronavirus denialist' who dangerously underestimates the threat the virus poses. ${ }^{8}$ According to Christiaens, Agamben's objections against the emergency measures of the Italian government are just the 'ramblings of a 77-year old man' who should be deplatformed as soon as possible.

Evidently, Agamben has been proven wrong in stating that Covid-19 is hardly different from the normal flu. Whereas patients suffering from flu die from that disease in around $0.1 \%$ of the cases, the mortality rate of Covid-19 is clearly much higher, with recent estimates ranging from 1 to $4 \% .^{9}$ The present situation on Italian intensive care units is certainly not in line with Agamben's dismissal of public concern on the outbreak of the coronavirus as a case of unwarranted mass hysteria. That is not to say, however, that Agamben's remarks on the governmental response to the outbreak should be disparaged - as Christiaens does - as nothing but some incoherent statements of an elderly philosopher. As Agamben himself explains in a blog post of 11 March, the current response to the outbreak could result in a 'degeneration of human relationships' that may outlast the

6 Giorgio Agamben, L’invenzione di un'epidemia, 26 February 2020, www.quodlibet.it/giorgioagamben-l-invenzione-di-un-epidemia (accessed 28 March 2020); see also www.journalpsychoanalysis.eu/coronavirus-and-philosophers/ for an English translation (last accessed 28 March 2020).

7 Slavoj Žižek, 'Monitor and Punish? Yes, Please', 16 March 2020, www.thephilosophicalsalon.com/monitor-and-punish-yes-please/ (last accessed 28 March 2020).

8 Tim Christiaens, 'Must Society be Defended from Agamben?', 26 March 2020, www.criticallegalthinking.com/2020/03/26/must-society-be-defended-from-agamben/ (last accessed 28 March 2020).

9 See www.who.int/emergencies/diseases/novel-coronavirus-2019 (last accessed 28 March 2020). 
corona crisis itself. ${ }^{10}$ Out of fear of contagion, 'our neighbour is abolished', with real contact being replaced by the exchange of digital messages as its poor substitute. Indeed, such replacement is a particular threat to the future of universities, many of which tend to show themselves more than eager to transfer most of their lessons online - a much more cost-efficient way of teaching anyway. ${ }^{11}$

In a statement dating from 17 March, Agamben further clarifies his legitimate concern about modern societies that tend to sacrifice anything to security. ${ }^{12}$ In order to facilitate effective action against the outbreak, many countries across the globe have proclaimed the state of emergency. 'We are in a war' in which 'nothing should divert us' from fighting an 'invisible enemy', as French president Macron put it in a televised address to the nation. ${ }^{13}$ As we have recently become habituated to live in a state of perennial crisis and emergency, such belligerent talk of government officials can hardly strike us as unusual. With the protection of the 'bare life' of citizens having been promoted to a governmental task that overrides everything else, most people do not seem to realize that their life now runs the risk of being reduced to 'purely biological condition' that is bereft of its social and political dimensions. What is most worrisome, however, is not what happens today, but what will come after the crisis. Just as a real war like Wold War I has left us with barbed wire as a harmful contribution to society, the imagined war against the virus may ultimately result in the continued use of harmful technologies that curtail political life and restrict our freedom.

In a friendly reaction to Agamben's controversial blog post in February, Jean-Luc Nancy brings up a personal anecdote. ${ }^{14}$ When doctors decided that Nancy needed a heart transplant, Agamben was one of the very few of his friends who advised him not to listen to them. Now, almost thirty years later, Nancy is very happy that he has followed the advice of his doctors and not that of Agamben. In similar fashion, it seems advisable for us not to ascribe too much weight to Agamben's assessment of the corona crisis as far as it concerns his medical expertise. With regard to the danger of exceptionalism becoming the rule rather than an exception, however, his critique deserves to be taken very seriously. It seems likely that the coronavirus will continue to bother humanity for at least the coming years, soon to be followed, for sure, by other threats to our security that are as yet unknown. Let's hope that critical voices like those of Agamben will prevent us

10 Giorgio Agamben, 'Contagio', 11 March 2020, https://www.quodlibet.it/giorgio-agambencontagio (last accessed 28 March 2020).

11 Cf. Willem Schinkel et. al., Academics are not a Vital Profession', www.scienceguide.nl/2020/03/ academics-are-not-a-vital-profession/ (last accessed 28 March 2020).

12 Giorgio Agamben, 'Chiarimenti', 17 March 2020, www.quodlibet.it/giorgio-agamben-chiarimenti (last accessed 28 March 2020); see also www.journal-psychoanalysis.eu/coronavirus-andphilosophers/ for an English translation (last accessed 28 march 2020).

13 See www.elysee.fr/emmanuel-macron/2020/03/16/adresse-aux-francais-covid19 (last accessed 28 March 2020).

14 Jean-Luc Nancy, 'Eccezione virale', 27 February 2020, www.antinomie.it/index.php/ 2020/02/27/eccezione-virale/ (last accessed 28 March 2020); see also www.journalpsychoanalysis.eu/coronavirus-and-philosophers/ for an English translation. 
Lukas van den Berge

from accepting current emergency measures and biopolitical practices and policies as business as usual. 